\title{
Directed aromatic functionalization
}

\author{
Victor Snieckus
}

\section{Editorial}

\section{Address:}

Department of Chemistry, Queen's University, Kingston, Ontario, K7L 3N6, Canada

\section{Email:}

Victor Snieckus - snieckus@chem.queensu.ca
Beilstein J. Org. Chem. 2011, 7, 1215-1218.

doi:10.3762/bjoc.7.141

Received: 29 August 2011

Accepted: 29 August 2011

Published: 06 September 2011

This article is part of the Thematic Series "Directed aromatic functionalization".

Guest Editor: V. Snieckus

(C) 2011 Snieckus; licensee Beilstein-Institut.

License and terms: see end of document.
The title of this Thematic Series brings to the minds of most organic chemists the beautifully logical aromatic electrophilic substitution ( $\left.\mathrm{S}_{\mathrm{E}} \mathrm{Ar}\right)$ [1-5] and, to a lesser extent, nucleophilic aromatic substitution $\left(\mathrm{S}_{\mathrm{N}} \mathrm{Ar}\right)[2,6,7]$ reactions as taught to many generations of students in their first organic chemistry courses [8] (Figure 1). Being less steeped in history, radical nucleophilic substitution $\left(\mathrm{S}_{\mathrm{RN}} 1\right)$ [9] and vicarious nucleophilic substitution (VNS) [10-12], in spite of their considerable synthetic utility, are given sparse mention. By the time students reach the upper years of study, aromatic chemistry receives the label "classical" and is disregarded or relegated to brief coverage. Apart from in English schools [13], heteroaromatic chemistry suffers the same fate. As a consequence, a fresh graduate entering the pharmaceutical industry, who invariably faces a complex aromatic or heteroaromatic as his or her first target molecule, is either lost or must grope around with insufficient background knowledge.
Since the late 1970 s, over thirty years since the independent discoveries by Gilman and Wittig, the directed ortho metalation (DoM) reaction has trickled into the armamentarium of the synthetic chemist (but not significantly into textbooks $[8,14]$ ), as a general and rational strategy for the construction of polysubstituted aromatics and heteroaromatics [15-17]. While comparison with $\mathrm{S}_{\mathrm{E}} \mathrm{Ar}$ and $\mathrm{S}_{\mathrm{N}} \mathrm{Ar}$ should never be denied, the DoM approach offers incontestable ortho regioselectivity, mild conditions, and perhaps most significantly, broad post-DoM synthetic potential. As a result, it has been called upon, with increasing favor and frequency, by academic and medicinal chemists for small-scale synthesis and by process chemists for multi-kilogram scale routes for clinical candidates and commercial pharmaceuticals and agrochemicals [18-24].

Once an aryl metal species was available by DoM and metal-halogen exchange or metal insertion, the gates of the syn-

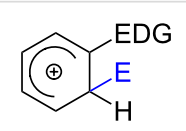

$S_{\mathrm{E}} \mathrm{Ar}$



$\frac{2}{S_{N} A r}$



3<smiles>[3H][TlH][CH]c1ccccc1OC</smiles>

4



5

Met $_{\text {Cat }}$ C-H Act

Figure 1: Directed aromatic functionalization methods. 
thetic arena were spectacularly opened to the 2010 Nobel Prize chemistry and the general theme of transition metal-catalyzed reactions. Thus, the named reactions of Kumada-Corriu, Negishi, Suzuki-Miyaura, Stille and, most recently, Hiyama have all given new insights into how $\mathrm{sp}, \mathrm{sp}^{2}$, and $\mathrm{sp}^{3}$, and $-\mathrm{O}$, $-\mathrm{N}$, and $-\mathrm{S}$ bonds are made to the aromatic ring carbon [25]. These strategies rapidly furnish biaryls/heterobiaryls, and condensed complex aromatics/heteroaromatics whose construction by previous generation methods (e.g., diazonium and radical coupling) has been clearly superseded by these venerable reactions $[26,27]$ especially to the benefit of the medicinal and process chemist [28].

The currently lively area of metal-catalyzed $\mathrm{C}-\mathrm{H}$ activation reactions (which has an early history but which commanded our attention by the publication of the Murai monograph $[29,30]$ ) is also causing a revolution in how we think about the preparation of aromatic/heteroaromatic molecules. Here, conceptually similar to the complex-induced proximity effect (CIPE) [31], which is operational in DoM reactivity, chelation of heteroatom groups to transition metals may be invoked, with an important exception [32-34], to rationalize ortho selectivity. The aromatic ring annulative chemistry, which can be achieved by $\mathrm{C}-\mathrm{H}$-activation mediated processes, perhaps best exemplified by goldcatalyzed reactions $[35,36]$, is astonishing and defies retrosynthetic analysis. While as yet mostly empirically derived, mechanistically inadequately defined, and practically untested, the $\mathrm{C}-\mathrm{H}$ activation methodologies will compete with, supersede, and replace our existing practices in synthetic aromatic chemistry in the next decade.

Perhaps of interest to the in-depth reader of this Thematic Series are a number of other methods for the synthesis of polysubstituted aromatics which are scattered, poorly systematized, and therefore underappreciated and primed for future reviews [3746].

What else is on the aromatic chemistry horizon? Within the area of DoM (and related metal-halogen exchange) chemistry, alternative and competitive combinational metal amide bases are rapidly appearing $[47,48]$. The first successful glimpses of the much sought after complementary, cleaner, regiodefined, and milder procedures to ortho, para versus meta $\mathrm{S}_{\mathrm{E}} \mathrm{Ar}$ reactions are being seen in $\mathrm{Cu}$-catalyzed meta-selective reactions [49,50]. The fleeting benzyne species, representing aromatic 1,2-dipole reactivity, is experiencing a renaissance due to milder and dependable methodologies for its generation [51,52]. Somewhat akin to $\mathrm{S}_{\mathrm{RN}} 1$ and, to a lesser extent VNS, the Minisci radical aromatic substitution chemistry [53] requires supplementary contemporary synthetic work in order to vigorously test its viability. The prospect of metal-catalyzed dehydrogena- tive conversion of cycloalkanes to aromatics as new source of aromatic feedstocks is also on the immediate horizon [54].

In this Thematic Series, you will find a fine assortment of forefront contributions in the field of manipulation and modification of aromatic compounds. Since it is a "moving" Series, my introductory comments required synchronization in order to adequately reflect the breadth of the contributions.

A cornucopia of reports, representative of the subject areas described above, demonstrates the current activity in aromatic chemistry. For example, the DoM reaction as applied to the construction of molecules of value for asymmetric synthesis is nicely presented by Rob Britton; lithiation chemistry in service of heterocyclic synthesis and modification is clearly demonstrated by the work of Jonathan Clayden, Jacques Mortier and Keith Smith; the major influence of DoM tactics are comprehensively demonstrated by the review of Marco Ciufolini; the new wave of very useful magnesiation and zincation is developed by Paul Knochel and Roberto Sanz; a hint of the potential of meta metalation by mixed metal/amide bases is posited by Robert Mulvey; and the application of such base combinations for the ready construction of planar chiral metacyclophanes is delightfully revealed by Donal O'Shea; striking evidence of the power of aryl metal species, derived from metal-halogen exchange, for transition metal-catalyzed cross-coupling reactions towards biaryl synthesis is furnished by Frederic Leroux; the next generation of heteroaromatic functionalization through $\mathrm{C}-\mathrm{H}$ activation may be gleaned from the review of the Rouen group presented by Christophe Hoarau. From the breadth of topic coverage, you will see that the "moving" Thematic Series covers a modern "moving" field.

I hope that the taste of topics covered vis-à-vis the above generalizations will stimulate the palate for the preparation of future Thematic Series highlighting progress in synthetic aromatic chemistry. My wish is that you will find the chemistry in this Thematic Series to your interest and utility, and hence read past the graphical abstract. I thank authors and all coauthors for their meticulously prepared contributions for which it has been my privilege to serve as editor.

Kingston, August 2011

Victor Snieckus

\section{References}

1. Smith, M. B.; March, J. Aromatic Substitution, Electrophilic. March's Advanced Organic Chemistry, 6th ed.; John Wiley \& Sons: Hoboken, NJ, 2007; pp $657 \mathrm{ff}$.

(For a concise but comprehensive background.) 
2. Smith, M. B.; March, J. Aromatic Substitution, Nucleophilic and Organometallic. March's Advanced Organic Chemistry, 6th ed.; John Wiley \& Sons: Hoboken, NJ, 2007; pp 853 ff.

(For a concise but comprehensive background.)

3. Taylor, R. Electrophilic Aromatic Substitution; John Wiley \& Sons: Hoboken, NJ, 1990.

4. Esteves, P. M.; de M. Carneiro, J. W.; Cardoso, S. P.; Barbosa, A. G. H.; Laali, K. K.; Rasul, G.; Prakash, G. K. S.; Olah, G. A. J. Am. Chem. Soc. 2003, 125, 4836-4849. doi:10.1021/ja021307w (Nitration: For a recent computational study.)

5. Barrett, A. G. M.; Bouloc, N.; Braddock, D. C.; Chadwick, D.; Henderson, D. A. Synlett 2002, 1653-1656. doi:10.1055/s-2002-34231 (Nitration: For recent synthetic developments; and references cited therein.)

6. Crampton, M. R. Nucleophilic Aromatic Substitution. In Organic Reaction Mechanisms, 1999; Knipe, A. C.; Watts, W. E., Eds.; John Wiley \& Sons: Chichester, UK, 2004; pp 283-284. doi:10.1002/0470094028.ch7 (For recent synthetic developments.)

7. Makosza, M.; Wojciechowski, W. Heterocycles 2001, 54, 445-474. doi:10.3987/REV-00-SR(I)2

8. Clayden, J.; Greeves, S.; Warren, S.; Wothers, P. Organic Chemistry; Oxford University Press: Oxford, 2001.

9. Rossi, R. A.; Pierini, A. B.; Peñéñory, A. B. Chem. Rev. 2003, 103, 71-168. doi:10.1021/cr960134o

10. Makosza, M. Chem. Soc. Rev. 2010, 39, 2855-2868. doi:10.1039/b822559c

11. Makosza, M.; Kwast, A. Eur. J. Org. Chem. 2004, 2125-2130. doi:10.1002/ejoc.200400034

12. Makosza, M.; Lemek, T.; Kwast, A.; Terrier, F. J. Org. Chem. 2002, 67, 394-400. doi:10.1021/jo010590z

13. Joule, J. A.; Mills, K. Heterocyclic Chemistry, 4th ed.; Blackwell Science: Oxford, 2000. (For the most pedagogic in English language.)

14. Smith, M. B. Organic Synthesis, 2nd ed.; McGraw-Hill: Columbus, $\mathrm{OH}$, 2001.

15. Hartung, C. G.; Snieckus, V. In Modern Arene Chemistry; Astruc, D., Ed.; Wiley-VCH: Hoboken, NJ, 2002; pp 330-367. doi:10.1002/3527601767.ch10

16. Macklin, T.; Snieckus, V. In Handbook of $\mathrm{C}-\mathrm{H}$ Transformations; Dyker, G., Ed.; Wiley-VCH: New York, 2005; pp 106-119.

17. Snieckus, V. Chem. Rev. 1990, 90, 879-933. doi:10.1021/cr00104a001

18. Dolman, S. J.; Nyrop, J. L.; Kuethe, J. T. J. Org. Chem. 2011, 76, 993-996. doi:10.1021/jo102275n (For Flow-DoM.)

19. Faigl, F.; Thurner, A.; Molnár, B.; Simig, G.; Volk, B. Org. Process Res. Dev. 2010, 14, 617-622. doi:10.1021/op100049t (For $200 \mathrm{~g}$ DoM.)

20. Gosselin, F.; Lau, S.; Nadeau, C.; Trinh, T.; O'Shea, P. D.; Davies, I. W. J. Org. Chem. 2009, 74, 7790-7797. doi:10.1021/jo901798d (For MK-7285, 4 kg scale synthesis.)

21. Hickey, M. R.; Allwein, S. P.; Nelson, T. D.; Kress, M. H.; Sudah, O. S.; Moment, A. J.; Rodgers, S. D.; Kaba, M.; Fernandez, P. Org. Process Res. Dev. 2005, 9, 764-767. doi:10.1021/op0501444 (For $60 \mathrm{~kg}$ scale.)
22. Thompson, A. S.; Corley, E. G.; Huntington, M. Improved synthesis of cyclopropylacetylene. WO1996022955A1 Aug 1, 1996. Chem. Abstr. 1996, 125, 221855. (For Sustiva ${ }^{\circledR}$ synthesis.)

23. Lo, Y. S.; Rossano, L. T.; Meloni, D. J.; Moore, J. R.; Lee, Y.-C.; Arnett, J. F. J. Heterocycl. Chem. 1995, 32, 355-357. doi:10.1002/jhet.5570320160 (For Sustiva ${ }^{\circledR}$ synthesis.)

24. Larsen, R. D.; King, A. O.; Chen, C. Y.; Corley, E. G.; Foster, B. S.; Roberts, F. E.; Yang, C.; Lieberman, D. R.; Reamer, R. A. J. Org. Chem. 1994, 59, 6391-6394. doi:10.1021/jo00100a048 (For Losartan (metric ton scale).)

25. Ackermann, L. Arylation reactions: A historical perspective. In Modern Arylation Methods; Ackermann, L., Ed.; Wiley-VCH: Weinheim, Germany, 2009; pp 1-24.

(For an insightful perspective on the historical development of cross-coupling reactions.)

26. Anctil, E. J.-G.; Snieckus, V. J. Organomet. Chem. 2002, 653, 150-160. doi:10.1016/S0022-328X(02)01164-6

27. Anctil, E. J.-G.; Snieckus, V. In Metal-Catalyzed Cross-Coupling Reactions, 2nd ed.; Diederich, F.; de Meijere, A., Eds.; Wiley-VCH: Weinheim, Germany, 2004; pp 761-813.

28. Torborg, C.; Beller, M. Adv. Synth. Catal. 2009, 351, 3027-3043. doi:10.1002/adsc.200900587 (For industrial applications.)

29. Murai, S., Ed. Activation of Unreactive Bonds and Organic Synthesis; Topics in Organometallic Chemistry, Vol. 3; Springer: Berlin, Heidelberg, Germany, 1999.

30. Kakiuchi, F.; Murai, S. Acc. Chem. Res. 2002, 35, 826-834. doi:10.1021/ar960318p

31. Whisler, M. C.; MacNeil, S.; Snieckus, V.; Beak, P. Angew. Chem., Int. Ed. 2004, 43, 2206-2225. doi:10.1002/anie.200300590

32. Hartwig, J. F. Chem. Soc. Rev. 2011, 40, 1992-2002. doi:10.1039/c0cs00156b

33. Maleczka, R. E., Jr.; Shi, F.; Holmes, D.; Smith, M. R., III. J. Am. Chem. Soc. 2003, 125, 7792-7793. doi:10.1021/ja0349857 (For a representative demonstration of potential.)

34. Hurst, T. E.; Macklin, T. K.; Becker, M.; Hartmann, E.; Kügel, W.; Parisienne-La Salle, J.-C.; Batsanov, A. S.; Marder, T. B.; Snieckus, V. Chem.-Eur. J. 2002, 16, 8155-8161. doi:10.1002/chem.201000401 (For iridium-catalyzed C-H activation - DoM strategies; and references cited therein.)

35. Toste, F. D. Beilstein J. Org. Chem. 2011, 7, 553-554. doi:10.3762/bjoc.7.63 (On this webpage, click "Show Thematic Series" for complete series.)

36. de Haro, T.; Nevado, C. Synthesis 2011, 2530-2539. doi:10.1055/s-0030-1260122

37. Fringuelli, F.; Taticchi, A. The Diels-Alder Reaction; John Wiley \& Sons: New York, 2002. (For cycloadditions.)

38. Boger, D. L.; Weinreb, S. M. Hetero Diels-Alder Methodology in Organic Synthesis; Academic Press: New York, 1987. (For cycloadditions.)

39. Bamfield, P.; Gordon, P. F. Chem. Soc. Rev. 1984, 13, 441-488. doi:10.1039/cs9841300441 (For de novo ring construction.)

40. Langer, P. Synlett 2009, 2205-2216. doi:10.1055/s-0029-1217554 (For significant rapidly developing methods based on Mukaiyama-Danishefsky-Brassard type reactions.) 
41. Castro, A. M. M. Chem. Rev. 2004, 104, 2939-3002. doi:10.1021/cr020703u

(For sigmatropic rearangements: Claisen.)

42. Nubbemeyer, U. Synthesis 2003, 961-1008. doi:10.1055/s-2003-39171

(For sigmatropic rearangements: Cope.)

43. Clark, J. S. Nitrogen, Oxygen and Sulfur Ylides: an overview. In Nitrogen, Oxygen and Sulfur Ylide Chemistry; Clark, J. S., Ed.; Oxford University Press: Oxford, 2002; pp 1-113.

(For sigmatropic rearangements: Sommelet-Hauser.)

44. Mori, K.; Sato, K. Tetrahedron 1982, 38, 1221-1225.

doi:10.1016/0040-4020(82)85107-7

(For dearomatization-rearomatization.)

45. Chandrasekaran, S.; Turner, J. V. Tetrahedron Lett. 1982, 23 , 3799-3802. doi:10.1016/S0040-4039(00)87711-4 (For dearomatization-rearomatization.)

46. Kikuchi, Y.; Hasegawa, Y.; Matsumoto, M. Tetrahedron Lett. 1982, 23, 2199-2202. doi:10.1016/S0040-4039(00)87299-8

47. Haag, B. A.; Sämann, C.; Jana, A.; Knochel, P. Angew. Chem. 2011, 123, 7428-7432. doi:10.1002/ange.201103022

48. Mulvey, R. E. Acc. Chem. Res. 2009, 42, 743-755. doi:10.1021/ar800254y

49. Phipps, R. J.; Gaunt, M. J. Science 2009, 323, 1593-1597. doi:10.1126/science.1169975

50. Chen, B.; Hou, X.-L.; Li, Y.-X.; Wu, Y.-D. J. Am. Chem. Soc. 2011, 133, 7668-7671. doi:10.1021/ja201425e (For a DFT calculational rationalization.)

51. Wenk, H. H.; Winkler, M.; Sander, M. Angew. Chem., Int. Ed. 2003, 42, 502-528. doi:10.1002/anie.200390151

52. Sanz, R. Org. Prep. Proced. Int. 2008, 40, 215-291. doi:10.1080/00304940809458089

53. Minisci, F.; Vismara, E.; Fonatana, F. Heterocycles 1989, 28, 489-519. doi:10.3987/REV-88-SR1

54. Izawa, Y.; Pun, S.; Stahl, S. S. Science 2011, 333, 209-213. doi:10.1126/science.1204183

\section{License and Terms}

This is an Open Access article under the terms of the Creative Commons Attribution License (http://creativecommons.org/licenses/by/2.0), which permits unrestricted use, distribution, and reproduction in any medium, provided the original work is properly cited.

The license is subject to the Beilstein Journal of Organic Chemistry terms and conditions:

(http://www.beilstein-journals.org/bjoc)

The definitive version of this article is the electronic one which can be found at: $\underline{\text { doi: } 10.3762 / \text { bjoc. } 7.141}$ 